\title{
Development Performance of Agriculture and Fisheries as Leading Program of Local Government and their Impact on People's Lives in Gorontalo Province, Indonesia
}

\author{
Jusdin Puluhulawa*, Hayatiningsih Gubali, Mohamad Ikbal Bahua \\ State University of Gorontalo, Indonesia. \\ *Corresponding author e-mail: puluhulawajusdin@gmail.com
}

\begin{abstract}
How to Cite: Puluhulawa, J., Gubali, H., \& Bahua, M.I. (2017). Development Performance of Agriculture and Fisheries as Leading Program of Local Government and their Impact on People's Lives in Gorontalo Province, Indonesia, Int. J. Agr. Syst. 5(2): 166-174.
\end{abstract}

\begin{abstract}
This research discusses two problems, namely the construction performance of agricultural and fisheries development and (2) their impact on community. The research employed qualitative research. The results showed that attainment of agricultural performance in the last five years, gave a quite significant impact on community. Along with the extensive development of the harvest and production, especially for commodity corn, growing on average per year (2012-2016) of 54.8\% reached 548,220 tons each year. Agricultural performance has given the economic impact to farmers, with contribution of agricultural sector in gross regional product of Gorontalo Province (30.35\% per annum). For the fisheries sector, the fisheries development is shown by the last of five years (20122016), both capture fisheries or fishing areas, the average growing 59,228.6 tons per year. The performance of this economic impact on fishing communities, demonstrated by the contribution of fisheries to GDP of the Province (2012-2016) of 20.06\% per year, and per capita income grew an average of $R p 12.51 \%$ per year. The second performance of the program impact was significant for society, particularly in the field of education, which is shown by the development of the school's participation numbers, the rate of literacy, and the use of education facilities of community expenditure above $95 \%$.
\end{abstract}

Copyright (C) 2017 IJAS. All rights reserved.

\section{Keywords:}

Agricultural and fisheries performance; local government; policies

\section{Introduction}

The ability to formulate policy and the measurement of the success of a leading program indispensable by the administrators in order to provide public goods and services in a professional problem. However, all the successes have just felt its impact (outcomes) when they are able to demonstrate accountability to the public.

The performance of the Organization of the public sector in general can be measured on a policy has been formulated according to community needs, were cast in a leading program. In public administration, performance is claimed to measure by emphasizing efficiency in the design of administrative system. According to Berman (2006) refers to a performance of the utilization of resources in an efficient and effective way to achieve results. These limits are the same as the concept of New Public 
Management (NPM) expressed by the Hood (1991). According to him the concept of New Public Management has the doctrine include: performance management concentrated, and performance assessment, results-based accountability, efficiency; and freedom of the manager to manage the organization.

The low accessibility and quality of public services that reflected through the performance of the bureaucracy of the public in a variety of organizing public services that occurred in those areas has raised various problems. Ranging from cultural, structural problems, "performance" as well as other problems faced by local governments. For Gorontalo Province, has analyzed the various problems encountered in the of Government.

The performance achieved by the government of Gorontalo Province, the measurement is not just limited to process input just like the availability of incentives, size of the budget, and outputs program activities. The performance has been achieved by the Government of Gorontalo Province in the last five years, demonstrate the effectiveness of the program, and provide a meaningful impact for the community.

The success of the government of Gorontalo Province, is more focusing on agriculture and the fisheries sectors. Performance agricultural sector is to increase broad harvest, with a target to income corn productivity and fisheries sectors (increase fisheries catch), increase income, absorving labor, reducing unemployment and giving contribution on economic growth. This research discusses two problems, namely the construction performance of agricultural and fisheries development and (2) their impact on community.

\section{Materials and Method}

\subsection{Approach}

Before discussing the issues above, the author will elaborate about research methods used i.e. qualitative methods. Bogdan and Taylor (1975), defining the qualitative method is descriptive research procedure generates data in the form of written or oral words of people and behavior is observed.

\subsection{Research Focus}

Research focus assignment according to Strauss and Corbin (2003), among others, aimed at limiting the investigation studies, qualitative research or problems in, resting on a focus (Lincoln and Guba, 1985). Then the focus of the study i.e. the performance development of agriculture and fisheries as the leading program of the local government as well as the impact people's lives in Gorontalo Province. For the farm include: "improve the vast harvest", and target rising corn, productivity and performance fisheries to raise capture fisheries and cultivation.

\subsection{Research Focus}

Research focus assignment according to Strauss and Corbin (2003), among others, aimed at limiting the investigation studies, qualitative research or problems in, resting on a focus (Lincoln and Guba, 1985). Then the focus of the study i.e. the performance development of agriculture and fisheries as the leading program of the local government as well as the impact people's lives in Gorontalo Province. For the farm include: "improve the vast harvest", and target rising corn, productivity and performance fisheries to raise capture fisheries and cultivation. 


\subsection{Instruments and Methods}

Main or research tools to collect the data are researchers themselves (Lincoln and Guba, 1985) or useful observations (Bogdan and Biklen 1982). While the method in analyzing this data refers to the theory that Miles and Huberman (1992) and the interactive model consist of three components, the analysis of which is "the reduction of data, and drawdown conclusion".

\section{Results and Discussion}

\subsection{Performance of Agriculture's Construction and Its Impact on Community}

The performance of agricultural development in the sphere of the leading program of provincial government policy of Indonesia, where the results achieved in the past five years, has brought a significant impact to people's lives. Along with the development of the vast harvest, and production, especially corn. Based on the data of agriculture and food crops of Gorontalo Province 2016, it shows that production of corn in the province since 2012 until the 2016 increased. Broad harvest corn in 2012 is 107.752 hectare and production reached 400.046 tons. While on 2016 broad harvest corn increased be 128,786 hectare with the production reached 548.220 tons.

Agricultural performance achievement is inseparable from the preparation of the agenda of the (setting) the correct and appropriate by the Government of Gorontalo Province, policy issues and will eventually be able to produce public policy. The results of this policy, according to Dye (1992) are "who decides what will be decided"? Who decides and what will be decided. Is a question that has extended the problem correctly and appropriately by the local authorities, in particular the development policy agenda, where the agricultural sector generally societies in Indonesia and rely on the source of income in the sector agriculture and fisheries. Policy-based agriculture and fisheries program is formulated is not without goals. The policy was drawn up in order to solve problems that are packed in the leading program as issues of emerging and growing hibiscus in the community.

Policy defined by Jones (1984) as "human needs, however identified, for which relief is sought. Human needs to be addressed or solved. Dunn (2004) identify the policy issue is the value, and the needs that have not been fulfilled but can be identified and reached by a public undertaking.

Realistically something policy, especially for the benefit of the crowd could not have avoided the problems that come up. Anderson (1979) suggests a public issue that can drive many people to think and look for the solution could appear to be a problem of policy. So that the public can be solved problems demands the formulation of problems with good and true. It fits with Dunn (2004), that the success of solving the problem will be right and defines problems through structuring problems.

At the start of the orientation changes the attitude of farmers, the government of Gorontalo Province are facing resistance heavy enough from farmers. The government takes the initiative to do innovation in increasing production of corn with the policy of the ministry in the form of the limited intervention of the Government (state limited intervention). One way is to give farmers the hope and certainty that by planting corn is profitable, a policy known as "the nine pillars agropolitan". This policy is sustainable agriculture development strategy, which is based on the idea that the success of agricultural development is to give economic impacts to farmers. This impact can be measured the contribution of agricultural sector in the GDP of Gorontalo Province. It shows a significant percentage compared with other sectors (Figure 2). 


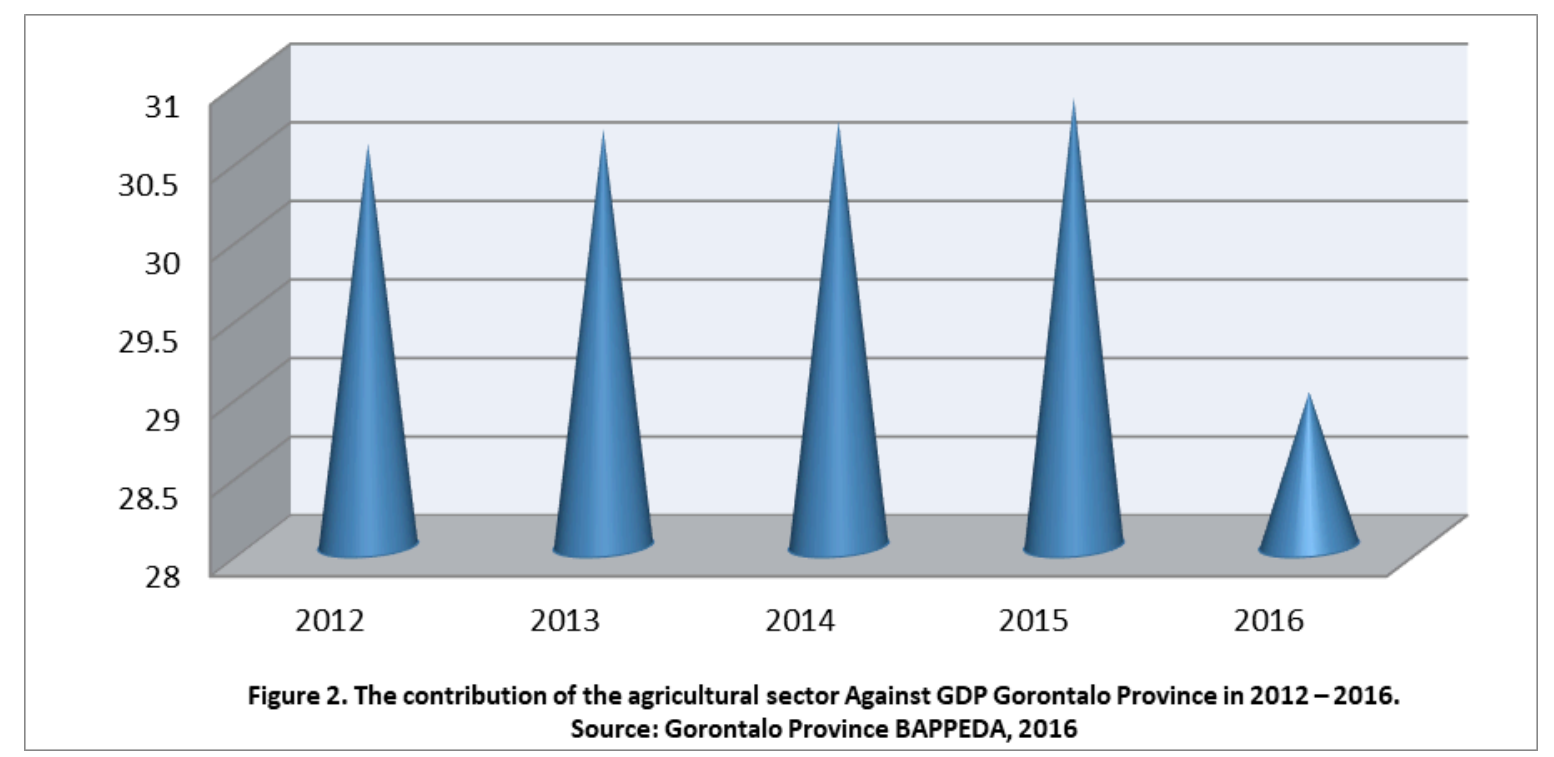

The contribution of the agricultural sector in 2012, against a GDP of Gorontalo Province, $30.56 \%$ in 2012 and 2013 amounting to $30.65 \%, 2014$ of $30.70 \%, 2015$ of $30.85 \%$ and decreased $28.98 \%$ in 2016, due to the long drought. The average yearly contribution of agriculture against the GDP of Gorontalo Province from years of 20122016 is of $30.35 \%$.

The availability of inputs for the acceleration of agricultural development as has been described above, and the performance has been achieved, namely "extensive harvesting and production of corn" (2002 - 2006) in Gorontalo Province, beginning in. This was supported by managerial bureaucracy, motivation and productivity of employees that are implementing leading edge development. With the achievement of a performance it can give positive results, impact to the lives of farming community. So with this performance of farmers feel satisfied, start opening up policy will accept and believe the agricultural leading program's corn based.

\subsection{The Performance of Fisheries Development and Its Impact on Community}

Development of fisheries policy is one of the leading programs of the provincial government of Gorontalo along the agricultural sector as a locomotive of economic growth have been revealing results. The performance of the fishery in Gorontalo is growing very significantly.

According to data from fisheries and maritime (2016), that the development of fishing production of Gorontalo Province of 2012 until the 2016 often find fluctuations, good the production of sub the fisheries sector catches and and the production of sub the fisheries sector cultivation. Production fisheries catch and fisheries cultivation increased from 46.026.10 tons in 2012 be 76.857.00 tons in 2015. While on 2016 production fisheries catch and fisheries cultivation decreased reached 46.677.00 tons. Decrease in fisheries production was more caused by natural factors i.e. high tide waves sea time is long enough.

Fisheries policies program in Gorontalo Province relevant to the meaning of the policy given by the United Nations (1975), basic guidelines for action, a direction of a specific action, a program that is planned (Wahab, 1997). The leading program of the fisheries policy, and agriculture by the government of Gorontalo Province is essentially as a guide to action from a program planned. In line with that Fredrick (in Islamy, 1997) gives the sense of a policy is a set of proposed actions a person, group or 
Government is in a particular environment by showing obstacles in the implementation of policies in order to achieve a particular goal.

Anderson (1979) confirms the interest policy an issue can be defined as a condition that produces needs or discontent on the people where the need to look for ways to overcome.Development program an when for increased production, and fishing income is policy program, known as the "Taxi Mina Bahari (TMB). The Government of Gorontalo Province has shown ability both in the management system as well as in improving performance of fishery with infrastructure to catching fish. This has brought on increased production capacity and supply the fish become more assured. Through a long process by exerting the whole potential of resources owned as input and output were excluded, the success of the Government of on this fisheries sector can impact for the economic life of the community. This impact can be demonstrated by the contribution of fishery on the GDP of Gorontalo Province lapse five years (2012-2016):

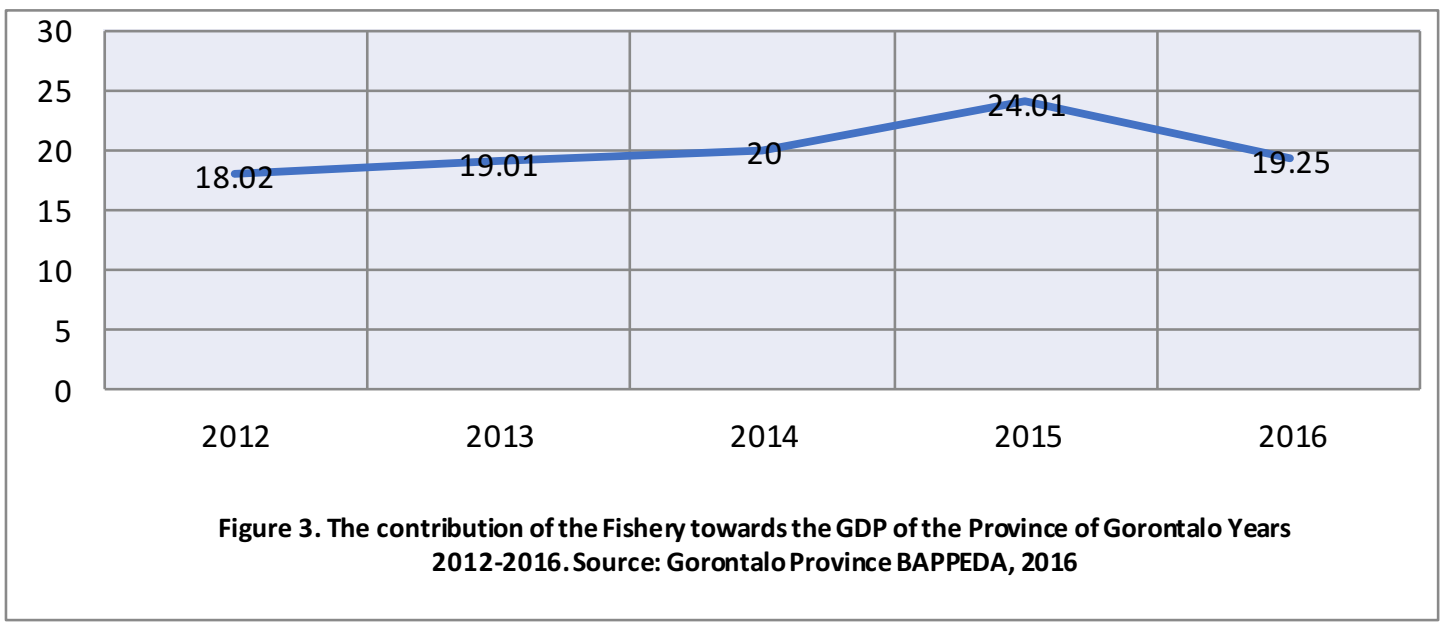

Those data, describes the product performance of the Government of Indonesia concerning the percentage contribution of the development of the fishery on the GRP (gross Regional domestic product) Province of Gorontalo. The contribution of the fisheries sector in 2012 on the GDP of Gorontalo Province was 18.02\%. 2013 amounting $19.01 \%, 20 \%$ by 2014,2015 amounting, $24.01 \%$, and decreased $19.25 \% 2016$, due to the high tide of the sea waves experienced by fishing communities. The average contribution of the fishery in GDP was 2012-2016 years of Gorontalo of $20.06 \%$.

See the development of product development performance of both these sectors namely, agriculture "performance" and "performance of the fishery" was part of the success of local government performance or Gorontalo Province in the leading program policy outlines that can be accountable to the community. Domai (2011) suggested the implementation of a policy closely with the human factor. This opinion is further emphasized by Lineberry (1978) which declared the policy implementation process have elements, among others: (a) the creation and arrangement of employees (as human beings) or assign the responsibility of implementation (b) resource allocation to the perfection of the impact of the policy.

The second performance of the leading program of significant impact for the life of the community, not just on a per-capita income, but its effects on other basic needs, namely the need for education. The development of education can be demonstrated with a number of the school's participation in Indonesia category prevalent in society.

The impact of education based on educational performance data in Gorontalo Province shows the number of the school's participation, the number of literacy and the 
use of the means of education to all graduate level of the community expenditure above $95 \%$. The success of the education sector in this policy human resource development programs in Gorontalo Province can provide benefits, and the impact for the community. Along with the success of the previous two leading programs namely performance development Agriculture and corn-based fisheries.

See the explanation above, shows that the public feel well catered and satisfied over the performance of the development achieved by the regional Government of Gorontalo Province in outlining policies two leading programs namely, performancebased agricultural development corn, and the performance of the construction of the fisheries. The second performance of the program is effectively inseparable from professionalism, accountability and the performance of local government employees in the task anyway.

This performance can benefit and a good impact to the economic income of the society at large. By itself a positive impact on other fields for the community. The impact of the performance of local governments democratically demonstrates the relationship between the Government of mutualisme with society that cannot be separated. According to Keban (2008) that the ability in making policy, and management functions, badly needed by the administrator to be able to provide the goods and services to the public in a professional manner. But all the new capabilities of the perceived benefits when they are able to demonstrate accountability for results to the public. Realization of public accountability is only shown in the form of performance, including the performance of the Government of Gorontalo Province and its officials.

Osborne and Gaebler (1992), Barzesley (1992), Osborne and Plastrik (1997) in the Reinventing Government demand that performance was no longer measured how the magnitude of input to reach output. The culmination of these demands is the enactment of the principle of "good governance" which strongly emphasized accountability and accountability with regard to the system of "checks and balances" in a system of institutional administration (Keban, 2008). Therefore, how important achievement and performance measurement as a real form of public accountability.

Pollitt and Boukaert (2000) suggested performance measurement practices developed extensively, intensively and external. The development of more extensive performance of "field work" include in performance measurement. Performance measurement more intensively "management functions" included in the measurement of performance. Whereas in external more "outsiders" are taken into account in the measurement of performance. Performance measurement good extensively, intensively and externally the estuary remains on efficiency and effectiveness in the achievement of results that can be accounted for in the community. Bernardin and Russel (1993) renders the performance is defined as "the record of outcomes produced on a specified job function or activity during a specified time period.". The meaning of this note about more emphasis on outcomes or results obtained after an occupation or activity is executed during a certain period of time.

Thus the performance of the Government of Gorontalo Province on the success of the policy program of the second seeded above a predetermined i.e. agricultural sector development performance, and fishing can give meaningful impact on people's lives. The performance of local government or organizational performance is the totality of the work that is within an organization. The success of the Gorontalo provincial government can provide and create prosperity for the people or the society as a form of public accountability. 
Managerial accountability is the responsibility of local Government to undertake the management of the Organization efficiently and effectively. Managerial accountability can also be interpreted as the performance accountability (performance accountability). Inefficiency of public organizations is to be the responsibility of the institution concerned in this case local government Province of Gorontalo and should not be charged to the client or customer. Local governments as publics sector organizations must account for the program have been made up on its implementation.

The success of the Government of Gorontalo Province in carrying out the policy of the two leading programs namely agriculture, construction and fisheries, would be tangible evidence of performance. The success of the regional Government of Gorontalo Province in the outlines of quality programs to the community described the achievement of organizational performance.

A public official (leader) who had a vision to the future, must understand very well the concept of performance, how to measure it, and how efforts or behavior leaders who can improve the performance of children's fruit and its organization. The term performanceis the translation of performance which is often translated by scholars as appearance, performance, or accomplishment (Asyhar, 2007). The Illustrated Oxford Dictionary (Asyhar, 2007) this term shows "the execution or fulfillment of duty" (implementation or achievement of a task), or a person's achievement under test conditions etc. (the attainment of results from someone when tested, etc.).

The two meanings of the performance above, though addressed to individual performance or the performance of the apparatus as a waiter, i.e. the appearance, performance or achievement is very relevant to the success of the organization. Moreover, the success of public sector organization is largely determined by the performance of the apparatus in carrying out tasks with an efficient and accountable results effectively, either in the leadership or to the community.

Assessment of the performance of the service users become very important because of the bureaucracy of the public often have the authority so that the users of the services of monopolis have no alternative sources of service. In a service conducted by the market, with the service users have the choice of service, the use of sources can reflect the satisfaction of service against the service givers. It is further emphasized by the Wibawa (1992), that performance can be assessed from the volume of services, quality of service and the ability to obtain resources for the implementation of the program.

\section{Conclusion}

The development of the agricultural sector within the scope of the Government's leading program policy Gorontalo Province, in the last five years, has brought a significant enough impact to people's lives. Along with the extensive development of the harvest, and the production of the commodity, particularly for corn, average grown annually (2012-2016) of $54.8 \%$ or the average development of the vast harvest of 125.358 ha of maize production in Gorontalo Province reaching 548,220 tons/year. The impact of this performance can be measured from the contribution of the agricultural sector in the gross regional domestic product (GDP) of Gorontalo Province showed a significant percentage average per year of $30.35 \%$. The performance of fishery in Gorontalo is growing very significantly, indicating fishery production last five years (2012-2016), both captured fisheries and aquaculture. With the concept of Taxi Mina Bahari (TMB) is fishing communities are slowly and surely has to understand its benefits and to increase the scale of its economic efforts. The performance of the Government of Gorontalo Province on these fisheries program policy can impact for 
the economic life of the community. This impact can be demonstrated by the contribution of fishery on the GDP of Gorontalo Province (2012-2016) on average of $20.06 \%$ annually, and percapita income communities grow on average per year (20122016 ) of $12.51 \%$. Another impact of the performance of the agricultural and fishery development on people's lives in Gorontalo Province, i.e. increasing the services in the field of development of education, in terms of human resources development.

\section{References}

Anderson, James. E. (1979). Public Policy Making, New York. NJ: Holt. Reinhartnwinston

Asyhar. (2007). Kinerja Pelayanan Publik (Studi Pelayanan Penyelenggaraan Ibadah Haji Pada Kantor Departemen Agama Kabupaten di Sampang), Disertasi. Program Pascasarjana, Universitas Brawijaya.

Bogdan, Robert C. and Steven J. Taylor (1975) Introduction to Qualitative Research Method, John Wiley \& Sons, Boston. (1992) Pengantar Metode Penelitian Kualitatif, (Translated), A. Chosin Afandi, Usaha Nasional, Jakarta. (In Indonesia).

Barzelay, M. (1992). Breaking Through Bureaucracy: an new vision for managing in government, Los Angeles, CA: University of California Press.

Bernardin, H.J. and J.E.A. Russel, (1993). Human Reseource Management,MacGraw Hill, Inc, Singapore.

Berman, E.M. (2006). Performance and Productivity in Public an Non Profit Organization, Second Edition. Armonk, N.Y: ME. Sharpe

Bogdan and Biklen. (1982). Qualitative Recearch for Education: An Indroduction to Theory and Methods.Allyn and Bacon. Boston. London.

Domai, T. (2011). Soud Governance. Universitas Brawijaya Press. Malang. (In Indonesia).

Dunn, W.N. (2004). Public Policy Analysis: An Introduction. Third Edition. Upper Saddler River, N.J. Pearson Prentice-Hall.

Dye, Thomas R. (1992). Understanding Public Policy. Prince Hall, Englewood Cliffs, New Jersey, United State of America.

Hood. C. (1991). A Public Management for All Seasons. Public Administration. Journal of Administration. Vol. 69: 319.

Islamy, M. Irvan. (1997). Prinsip-Prinsip Perumusan Kebijaksanaan Negara, Bumi Aksara, Jakarta. (In Indonesia).

Jones, Charles, O, (1984). Pengantar Kebijakan Publik, Manajemen PT Raja Grafindo Persada, Jakarta. (In Indonesia).

Keban, T. Y. (2008). Enam Dimensi Strategis Administrasi Publik Konsep, Teori dan Isu, Gava Media, Jogyakarta. (In Indonesia).

Lincoln and Guba. (1985). Naturalistic Inquiry. London. Sage Publication.

Linebery, Robert. (1978). American Public Policy. Nort Western University Harper and Row Publisher. New York.

Miles, M.B. Huberman. A. M. (1987). Qualitative Data Analysis: A Sourcebook of New Methods. Beverly Hills. Sage Publications.

(1992). Qualitative Data Analysis. Translated by: Tjetjep Rohendi Rohidi, Analisis Data Kualitatif, Universitas Indonesia, Jakarta. (In Indonesia). 
Osborne, D. and, Gaebler, T. (1992). Reinventing Government: How the Entrepreneurial Spirit Is Transforming the Public Sector. New York. Penguins Books.

Osborne, D. and P. Plastrik. (1997). Banishing Bureaucracy: The five Strategies for Reinventing Government, Reading, MA: Addison-Wesley Publishing Company, Inc

Pollitt,C., and G., Bouckaert. (2000). Public Management Reform: A Comparative Analysis. London: Oxford University Press.

Pasolong dan Harbani. (2007). Teori Administrasi Publik. Alfa Beta. Bandung. (In Indonesia).

Strauss, A. and Corbin, J. (2003). Basic Of Qualitatif Research, Terjemahan, Muhammad Shodiqdan Imam Muttaqien, Dasar-Dasar Penelitian Kualitatif, Pustaka Pelajar, Yogyakarta. (In Indonesia).

Wahab. Abd. Solichin. (1997). Analisis Kebijaksaaan: dari Formulasi ke Implementasi Kebijaksanaan Negara, Edisi kedua, Bumi aksara. Jakarta (In Indonesia).

Wibawa, Samudra. (2001). Neues Steuerungs model, Belajar Otonomi dari Jerman. ISTAWA. Yogyakarta. (In Indonesia).

Widodo, Joko. (2001). Good Governance, Telaah dari Dimensi Akuntabilitas dan Kontrol Birokrasi, pada era Desentralisasi dan Otonomi Daerah, Insan Cendekia, Surabaya. (In Indonesia). 